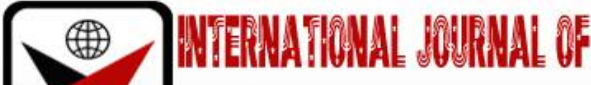

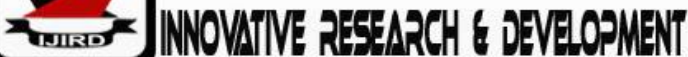

ISSN 2278-0211 (Online)

\section{Effect of Credit to Private Sector on Gross Capital Formation in Rwanda (2004-2016)}

\author{
Muhayeyezu Josoph Desire \\ Planning and Monitoring Specialist/ Minema, School of Business, \\ Jomo Kenyatta University of Agriculture and Technology (Jkuat), Kenya \\ Mulyungi Mwendandu Patrick \\ Lecturer, School of Business, \\ Jomo Kenyatta University of Agriculture and Technology (Jkuat), Kenya
}

\begin{abstract}
:
The credit to private sector plays an important role in the development of many countries as it boosts investment in creation of stock of fixed assets through gross capital formation. The Government of Rwanda encourages the private sector contribution in boosting the economic growth of Rwanda. The Gross Capital formation speeds up a country's economic growth since it contributes to improved national output through change in fixed assets and inventory and creation of employment through rapid investment. The purpose of this study was to analyze the effects of credit to private sector on gross capital formation in Rwanda (2008-2017) using VAR approach. The study adopted quantitative descriptive research design. Time series data for the period 2004 to 2016 regarding the variables were sourced from BNR, NISR and WHO reports. the analysis of data was aided by E-Views software and presentation of findings was done in tables and graphics. The research is important to government policy makers as it provides appropriate strategies to increase capital accumulation in Rwanda hence accelerating economic growth through promotion of credit to private sector (CPS). Cointegration results indicated existence of a long run relationship between credit to private sector and gross capita formation. There is positive significant effect of credit to private sector on gross capital formation in Rwanda. The study findings further indicate that credit to private sector accounted for 95.49\% of deviations in gross capital formation. The study recommends that the government should encourage credit advancement to private sector so that private actors are able to undertake investments in capital accumulation to improve production and create employment, hence speed up economic growth of Rwanda.
\end{abstract}

Keywords: Gross capital formation, economic growth, credit to private sector, domestic savings, foreign capital

\section{Introduction}

Most of developing countries emphasize on credit creation for the private sector as it affects the capital formation as a major driver of the economic development. The credit to private sector and gross capital formation has been discussed by many economists and accountants upon their role in economy.

Between 1975 and 1982 most of European countries suffered a period of economic stagnation. For the rest of 1980s, a major aim was to establish all possible policies to boost up again their economies. The emphasis was put on gross capital formation through all means of interventions mainly increasing government spending, promoting credits to private sector, attracting foreign investment.... All sectors had to increase purchases of physical capital goods. Capital goods are goods that are used to produce other commodities. Thus, investment and capital formation are one and the same. (David BEGG et al 2010).

Capital formation forms a great pillar of economic growth. Capital formation is composed of capital stock additions like equipment and buildings among other intermediate goods (Uremadu, 2009). The production of goods and services by a country is enhanced through combination of capital stock and labor.

Contradictions have arisen on capital formation strategies. According to a section of economists, capital formation involves transfer of saving from household and government to the business sector, resulting in an increased output and expansion. (David BEGG et al: 2010).

This has been balanced because many countries do not have a sufficient national saving to provide a strong capital formation. It is also true that most of developing countries have a small saving and even some of them a negative saving. Does it mean that in these countries there is no capital formation process? It is totally wrong! So, there are other ways to boost up the capital formation in nations. The credit to private sector is one of these ways to boost gross capita formation. All developing countries and Rwanda in particular do their best to accelerate economic growth through productive capacity expansion. According to Harrod- Domar (1946) gross capital formation is directly related economic growth of a country. 
The government of Rwanda's commitment is to create a favorable investment climate. This commitment is presented in the Vision 2020 where it has a strong pillar of "Development of Entrepreneurship and private sector". To achieve this goal, the GoR has established policies and agencies to regulate the investments and public sector. Some strategy documents have been drafted to guide towards achieving the goal. For example, EDPRS II which runs for a period of 5 years from 2013 to 2018 aiming at reducing poverty, speed up rate of economic growth and direct economy towards industrialization.

The impact of credit to private sector as one of the gross capital formation factors on GDP has been discussed by many economists and researchers all over the world and in most countries such as Ghana and members of European Union. Evidences have shown that C gross capital formation factors influence the level of economic growth (Antwi, Mill and Zhao (2013). Thus, creating enabling environment of these factors such as credit to private sector

\subsection{Statement of the Problem}

The credit to private sector contributes to creation of stock of fixed asset which are the major component of gross capita formation. The contribution of gross capital formation on Rwanda's GDP is still comparably low compared to other nations yet the achievement of vision 2020 calls for rapid growth of capital stock (EDPRS 2) According to National Bank of Rwanda (2015), Gross capital formation accounted for 18\% and 34.4\% of GDP in 2007 and 2015 respectively which is a great improvement overtime. The components of gross capital formation aim at increasing level of fixed assets and inventory changes. The government of Rwanda emphasizes on this indicator of development to build up infrastructures, to adopt modern techniques of production, to improve qualitatively human resources, to utilize properly natural resources, to boost up technological progress, to develop agricultural and industrial sector, to meet higher rate of growth in national income, to expand economic activities, to build import substitution industries and then reduce foreign debt by increasing national revenues from taxable elements (BNR, 2015).

Considering its economic contribution, the gross capital formation helps to enhance productive capacity of Rwandan economy. Given its role in the development, the government ought to tackle on interest rate on credit to private sector, which remain relatively high, to boost the stock of capital goods.

Rwanda does its best to promote capital formation, especially in electricity, roads, schools, industries, mechanization of agriculture, hospitals' construction. Hence it contributes much to economic growth.

Many studies have been carried out to analyze how gross capital formation is related to economic growth in many countries (Ajose \& Oyedokun, 2018) but few exists on factors influencing gross capital formation specifically on credit to private sector. Moreover, the few studies give different findings on the same. This study therefore explored the same area taking Rwandan case, focusing on credit to private sector and using the vector autoregressive model and annual time series data from 2004-2016.

\subsection{Research Objective}

To assess the influence of credit to private sector on gross capital formation in Rwanda.

\subsection{Research Hypothesis}

- Ho2: Credit to private sector has significant influence on gross capital formation in Rwanda.

\section{Literature Review}

\subsection{Harrod-Domar Growth Theory}

The model was developed by Roy F Harrord and Evsey Domar in 1946. The underlying principal of this theory is active savings mobilization and then utilizing the savings to generate investments which ultimately speeds up rate of economic growth which is a necessary condition towards development. This theory explains the mechanism by which capital formation leads to growth. According to this theory, investment comes from savings and the rate of economic growth (GNP growth rate) is determined jointly by the ability of the economy to save (savings ratio) and the capital-output ratio. (Ray, Debraj, 2005)

This model is popular in development economics and is widely used to explain a country's rate of growth as heavily depending on saving rate and capital productivity. it postulates that a balanced growth of an economy is independent of natural phenomenon.

Assumptions of this model include:

1. Output is a function of stock

$\mathrm{Y}=\mathrm{f}(\mathrm{K})$

2. Constant returns to scale production function therefore the marginal productivity of capital is constant. This brings equality of marginal productivity and average productivity of capital.

3. Capital is necessary for output

$$
\frac{d Y}{d K}=\frac{Y}{K}=c
$$

$\mathrm{F}(0)=0$

4. The product of the savings rate and output equals saving which equals investment

$$
s Y=S=I
$$


5. Investment minus depreciation of stock of capital measures the change in capital stock.

$$
\Delta K=I-\delta K
$$

The derivation of the output growth rate is computed in the following way:

From the assumptions 1 to 3 output and capital are related in a linear form. are linearly related hence growth rate of capital and output are equal.

Since the productivity of extra unit of capital c is fixed,

$$
Y=c K \rightarrow \log Y=\log c+\log K
$$

$\dot{Y}$ and $K$ are percentage growth rates of $\mathrm{K}$ and $\mathrm{Y}$.

$$
\frac{d \log Y}{d t}=\frac{d \log K}{d t} \rightarrow \frac{\dot{Y}}{Y}=\frac{\dot{K}}{K}
$$

Incorporating 4 and 5, the rate at which capital grows is stated as,

$\frac{\dot{Y}}{Y}=s c-\delta$ (Harrod, Roy F. 2010).

$$
\frac{\dot{K}}{K}=\frac{I}{K}-\delta=s \frac{Y}{K}-\delta
$$

From this equation, the implication is that growth of output is equated to the difference between the product of saving rate and marginal productivity of capital and rate of depreciation. Therefore, according to the model, higher growth rates is associated with higher savings and higher marginal productivity of capital and lower depreciation. (Domar Evsey, 1946). According to this model more investment on capital and labour boosts accumulation of capital hence higher economic growth is attained. The model explains why capital accumulation is sluggish in LEDCs. This scenario is explained by higher labour supply in these countries but low supply of physical capital in addition to lower incomes which discourages savings and investment hence low economic growth. (Domar Evsey, 1946). The model is relevant to this study since the study aims to determine the factors that can speed up the rate of capital stock in Rwandan economy.

Lastly according the model, to achieve economic growth countries should come up with investment growth policies which stimulate higher savings and ultimately technological advances.

\subsection{Credit to Private Sector, Capital Formation and Economic Growth}

Rwanda has continued to focus on private sector expansion as a strategy to spur economic growth. This was evidenced by the World Bank report of 2016(New times, 2016) where the World Bank hailed Rwanda for continued private sector growth which has contributed greatly to its sustainable economic growth. From this report it can be concluded that credit to private sector has positive significant effect on economic growth.

Lucky \& Uzah (2016) conducted a study in Nigeria on determinants of capital formation. Using time series secondary data from 1981-2014.the findings revealed that credit to private sector has a positive but insignificant effect on capital formation. They recommended deepening of financial sector of Nigeria and more finance be channeled to infrastructure development to discourage capital flight.

A study was carried out by Ojimadu P (2016) in Nigeria on relationship between bank credit and capital formation using secondary time series data. For a period of 34 years from 1980 to 2014. The findings indicated that bank credit and capital formation were moving in the same direction meaning a positive significant effect of bank credit on capital formation. Author commented that the insignificance was due to bottlenecks and tight rules on credit allocation by banks. The study therefore recommended that flexibility should be adopted by banks when it comes to credit allocation in order to boost capital formation.

Dushimumukiza (2010) and Julian and Shukla (2017) conducted a study on financial development and economic growth in Rwanda and EAC respectively. The results of the former found no evidence of private sector credit playing a significant role in promoting economic growth whereas the later found evidence of private sector credit being critical in promotion of economic growth among EAC Countries.

Kablan (2010) study on banking efficiency and financial development in sub-Saharan Africa indicated that loans to private sector in Sub Saharan Africa is comparably low in percentage than in Latin America and Asian countries. This explained the reason why the sub Saharan Africa lags behind in terms of economic growth. This is an indication that there is a significant positive effect of credit to private sector on economic growth. Increased credit to private increases capital accumulation through business expansion hence economic growth.

Maureen et al (2012) in Kenya assessed the association between private sector credit and economic growth. The study found that private sector credit positively and significantly affects economic growth. The findings were however contradictory to those of Kagochi J (2013).

According to Emmanuel et al (2015) long run association exists between private sector credit and economic growth in Nigeria. Further private sector credit significantly affects economic growth according to VECM results 


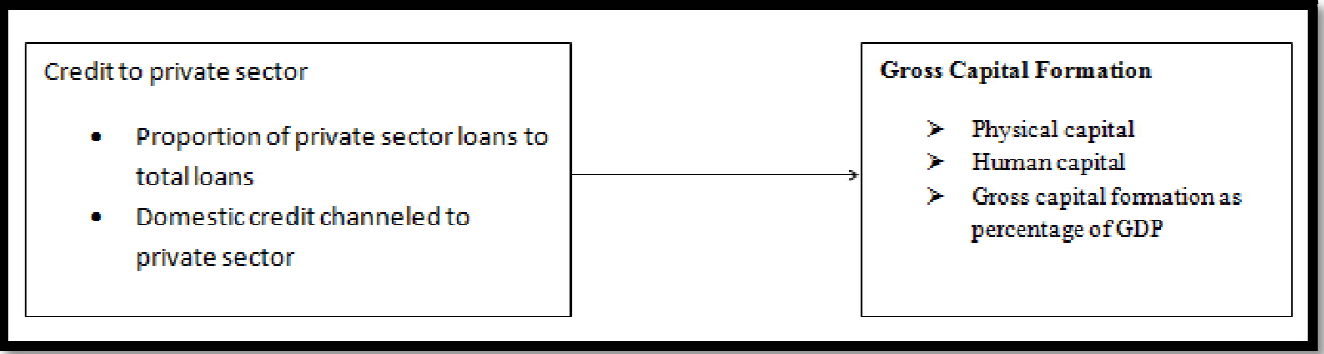

Figure 1: Conceptual Framework

Source: Researcher, 2019

\section{Methodology}

This study adopted both descriptive quantitative and qualitative research design. Quantitative research design consists of employing an econometric model to study the long run as well as the short run relationships between the variables of interest.

Time series secondary data for the period 1995-2015 were used. This period was chosen since it is the period that was characterized by need for improved capital formation to heal Rwanda's economy which had just suffered a blow from the Genocide of 1994 perpetrated against Tutsi and also needs for capital formation in order to enable Rwanda achieve her short and long term development ambitions. Data on the variables under study that is Gross Capital Formation and credit to private sector was sourced from BNR, NISR, World Bank database and statistical reports and bulletins.

The study adopted Harrod-Domar model of growth developed by Harrod and Domar in 1946. According to this model the output which measures economic growth is a function of capital stock. The model emphasizes the need for savings to create capital stock.

$\mathrm{Y}=\mathrm{f}(\mathrm{k})$ where $\mathrm{Y}$ is output and $\mathrm{K}$ is capital stock. Capital stock accumulation in an economy depends on several factors in an economy. This study therefore opens up the model to include credit to private sector as capital stock factor. The relationship between gross capital formation and credit to private sector is presented in linear form as shown below.

$Y=\lambda o+\lambda 1$ creps $+\varepsilon t$

Where

$Y \Rightarrow$ Gross capital formation

creps $\Rightarrow$ Credit to private sector

$\lambda 0 \Rightarrow$ Constant term

$\lambda 1, \Rightarrow$ Coefficients

Data analysis was done using E-Views and presented in form of tables and graphs. The analysis included conducting unit root test, co integration test, VAR analysis using impulse response technique and causality tests.

\section{Findings and Discussion}

\subsection{Unit Root Tests}

The researcher tested the following hypothesis for stationarity of data set.

- Ho: Presence of unit root in the data set

- $H 1$ : No unit root in the data set

Decision criteria: The null hypothesis is rejected if the probability is less than $5 \%$ otherwise, we fail to reject.

From the findings in the table 1 below, the probabilities for all variables at level are greater than $5 \%$ hence we accept null hypothesis of presence of unit root hence no stationarity at level. At the first difference, the probabilities for all variables are less than $5 \%$ hence we reject null hypothesis of presence of unit root and conclude that the data set is stationary at first difference.

\subsubsection{ADF Test}

\begin{tabular}{|c|c|c|}
\hline Variable & Prob. at level & Prob at 1 ${ }^{\text {st }}$ difference \\
\hline Gross capital formation & 0.5780 & 0.0000 \\
\hline Credit to private sector & 0.5841 & 0.0002 \\
\hline
\end{tabular}

Table 1: Unit Root Test Results

Source: Researcher, 2019

\subsection{Cointegration Test}

Cointegration is the existence of long run relationship between two or more variables. The researcher achieved this by carrying out Johansen Cointegration test. The findings are shown in the below table. 


\begin{tabular}{|c|c|c|c|c|c|c|}
\hline $\begin{array}{c}\text { Hypothesized } \\
\text { No of CEs }\end{array}$ & $\begin{array}{c}\text { Trace } \\
\text { statistics }\end{array}$ & $\begin{array}{c}\text { Crit.val. } \\
\mathbf{0 . 0 5}\end{array}$ & p-value & Max.Eigen st. & $\begin{array}{c}\text { Critical } \\
\text { value 0.05 }\end{array}$ & p-value \\
\hline None* & 53.756 & 47.85613 & 0.0152 & 29.68700 & 27.5843 & 0.0069 \\
\hline At most 1 & 17.06936 & 29.79707 & 0.6350 & 9.418038 & 21.13162 & 0.7974 \\
\hline At most 2 & 7.651318 & 15.49471 & 0.5034 & 7.602639 & 14.26460 & 0.4205 \\
\hline At most 3 & 0.048679 & 3.841466 & 0.8254 & 0.048679 & 3.841466 & 0.8254 \\
\hline
\end{tabular}

Table 2: Johansen Cointegration Results

Source: Researcher, 2019

Table 2 above shows the findings for both trace statistics and maximum Eigen value statistics. Both statistics tests revealed one cointegrating equation at 5\% level of significance. The null hypothesis of no cointegration among the variables was rejected at none since the p values of 0.0152 and 0.0069 for trace and maximum Eigen value were less than 0.05 and the statistical values were more than the critical at none cointegrating equations. This is a confirmation that there is a long run relationship between the gross capital formation and credit to private sector.

\subsection{Multiple VAR Estimates}

The study analyzed the factors influencing gross capital formation in Rwanda by adopting the Vector Auto regression method. The results indicated the magnitude and direction of change of dependent variable per unit change of independent variable at 2 lags. The researcher conducted multiple VAR analysis to determine the magnitude of change of gross capital formation due to a unit change in credit to private sector. The findings show that the coefficient for CREPS and constant term are 0.046 and 1.46 respectively taking GCF as the dependent variable. The R squared value was found to be 0.9549 equivalents to $95.49 \%$. The linear VAR model becomes,

$g c f=1.460+0.046$ creps $+\varepsilon t$

\subsubsection{Dependent Variable: Gross Capital Formation}

\begin{tabular}{|c|c|c|}
\hline Independent variables & coefficients & prob \\
\hline Credit to private sector & 0.046 & 0.0030 \\
\hline constant & 1.46 & 0.0043 \\
\hline
\end{tabular}

The results show the VAR matrix where series are in causal relation with the series used in the model and the findings conclude positive causal relations between all series as the coefficients are positive. Later, the researcher undertook the impulse functions as other researchers have done to confirm these findings (Gitahi, 2012)

The findings infer that a change of one unit in credit to private sector leads to 0.046 units change in Gross capital formation keeping other factors constant.

\subsection{Granger Causality Test Findings}

The researcher carried out VAR Granger causality test on the variables under study. The findings in the below table indicate that the probability for CREPS is 0.0004 which is less than 0.05 .

\subsubsection{Block Exogeneity Wald Tests}

\begin{tabular}{|c|c|c|}
\hline Dependent variable: GCF & Chi-Sq & Prob. \\
\hline Credit to private sector & 1.385 & 0.0004 \\
\hline
\end{tabular}

Table 4: Granger Causality Test

Source: Researcher, 2019

\subsection{Impulse Response of Gross Capital Formation to Private Sector Credit Shocks}

The researcher computed the impulse response of gross capital formation to Credit to private sector shocks. There were mixed reactions of the responses. Initially there was a positive response and towards the end of the study period there was a negative response of GCF to CREPS. In the first five quarters the response is positive but after the response becomes negative, this may be due to macroeconomic and policy changes. 


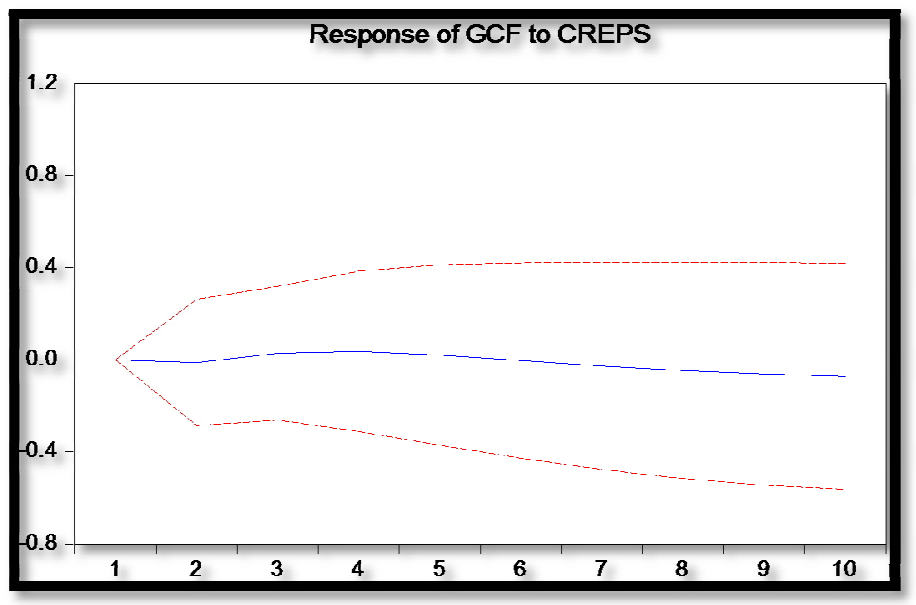

Figure 2: Response of GCF to CREPS Shocks

Source: researcher, 2019

\subsection{Discussion}

There is a long run relationship between credit to private sector and economic growth as shown in cointegration findings. The multiple regression findings also show that there is positive significant effect of credit to private sector on economic growth in Rwanda. A unit increase in credit to private sector increases the gross capital formation by 0.046 units ceteris paribus. In a liberalized economy, private sector plays an important role in stimulating econ0omic growth since it forms the better part of investment in the business sector and other sector as well. This therefor e means that if the private sector if adequately financed and such finance channeled to undertake productive investments, this will boost total output in the economy and create jobs for people hence improved living standards. Credit to private sector and GCF granger causes one another meaning that one can influence the other according to granger causality test findings. Lastly on the impulse response results, there is positive response of GCF on a shock of credit to private sector in the first quarters years under consideration and then the response becomes negative in the next years (after 6 year). A positive shock on credit to private sector for example reduction in credit channeled to private, the GCF will welcome this positively and reverse happens when there is a negative shock. The findings are similar to those of Julian and Shukla (2017) who found along-run relationship as well between credit to private sector and gross capital formation a proxy for economic growth within the EAC. The findings are also similar to those by Emmanuel et al (2015) Nigeria who also found a long run relationship between the private sector credit and capital accumulation hence economic growth and also positive significant effect between the two variables. The findings however contradict those of Ojimadu (2016) and Lucky \& Uzah (2016 who found a positive insignificant effect of bank credit and private sector credit respectively on capital formation in Nigeria.

\section{Conclusion and Recommendations}

\subsection{Conclusion}

From the findings regarding the influence of credit to private sector on GCF in Rwanda, the researcher concludes that there is a positive significant influence of credit to private sector on Gross capital formation. The VAR model results indicates that $1 \%$ change in private sector credit leads to a $4.6 \%$ change in gross capital formation in the same direction keeping other factors constant. Further, the granger causality test findings indicate that private sector credit granger causes gross capital formation since the probability is less than 5\%. Lastly from the impulse response findings it can be concluded that gross capital formation responds positively to private sector credit shocks though it fizzled out to the negative side towards the end of the study period. This could be due to reduced impact of CREPS on GCF towards the end of study period.

\subsection{Recommendations}

The government should encourage credit advancement to private sector so that they are able to undertake investments, improve output and create employment hence speed up rate of capital accumulation and economic growth. This can be achieved through lowering interest rates to the commercial banks so that they are able to get enough capital at a cheaper cost which will ultimately improve their liquidity position enabling them to lend more to the private investors at a cheaper cost too.

\section{References}

i. Ajose \& Oyedokun(2018). Capital Formation and Economic Growth in Nigeria. International Accounting and Taxation Research Group. University of Benin. Vol. 2 No. 2.

ii. Antwi et al(2013). Impact of Macroeconomic Factors on Economic Growth in Ghana.: A Cointegration Analasys. International Journal of Academic Research in Accounting, Finanace and Management Sciences. Vol. 3 No. 1.

iii. Bakare S.A. (2011). A Theoretical Analysis of Capital Formation and Growth in Nigeria. Far East Jouirnal of Psychology and Business, 3(2), 11-24.Man

iv. BNR. (2015). BNR Economic Review. Kigali: National Bank of Rwanda. 
v. Charles et al. (2014). VAR Analysis of Economic Growth, Domestic Investment, Foreign Direct Investment, Domestic Savings and Trade in Rwanda. Greener Journal of Economics and Accountancy, 3(2), 030-041.

vi. Creswell et. al. (2018). Research Methodology. Methods and Techniques. New Delhi: New Age International Publishers.

vii. $\quad$ David B. et al. (2010). Economics 10th Edition. Mc GrawHill Publishers..

viii. Dhanya Jagadeesh(2015). the Impact of Savings on Economic Growth: An Empirical Study Based on Botswana. International Journal of Research in Business Studies and Management.2(9), 10-21.

ix. $\quad$ Domar E. (1946). Capital Expansion, Rate of Growth and Employment. Econometrica, 14(1) 30-40.

x. Dushimumukiza. (2010). Financial Development and Economic Growth in Rwanda. Masters Thesis. Mauritius: University of Mauritius.

xi. Enders \& Lee. (2004). Testing for Unit Root with a non Linear Fourier Function. Econometrics Society. Econometric Society.

xii. Engle R.F \& Granger,C.W.J. (2012). Co-integration and Error Correction Representation Estimations and Testing. Econometrica, 35: 257-276.

xiii. Frank \& Shukla. (2018). Econometric Analysis of Determinants of FDI in East Africa(2005-2015). Case Study of Kenya, Uganda and Rwanda. International Journal of Economics Commerce and Management, Vol VII Issue 6.

xiv. Gbenga \& Adeleke. (2013). Savings, Gross Capital Formation and Economic Growth Nexux in Nigeria(1975-2008). IOSR Journals of Economics and Finance, 1(2), 19-25.

xv. Ghura D \& Hadji M.T. (2013). Growth in Sub-Saharan Africa, Staff Papers. Washington D.C: International Monetary Fund.

xvi. Gitahi N.(2012). Effects of Fiscal Policy on Private Investment in Kenya(1964-2010. Kenyatta University Repository. Nairobi Kenya. 1-95.

xvii. Gungor \& Olesia. (2014). What is the Impact of Savings on Growth?. The case of a Small open Economy (Albania). Mediterannean Journal of Social Sciences, 5(13), 360-368.

xviii. Harrod R.F. (2010). An Essay in Dynamic Theory. Economic Journal, 49(10) 5-20.

xix. Kablan S. (2010). Banking Efficiency and Financial Development in Sub Saharan Africa. International Monetary Fund.

xx. Kothari C.R. (2011). Research Methodology. Methods and Techniques. New Delhi India: Prentice Hall Publications.

xxi. Lucky \& Uzah(2016). Determinants of Capital Formation in Nigeria. ATest of Jhingan's Preposition $1981-2014$. IIARD International Journal of Banking and Finance Research. vol. 2 No. 1 page 1-19

xxii. Mugenda \& Mugenda. (2013). Research Methods. Quantitative and Qualitative. Nairobi: Africa Centre for Technology.

xxiii. New Times. (2016). World Bank Credits Private Sector Growth with Rwandas Economic Stability. The Daily Newtimes Rwanda Newspaper. Kigali: New Times. 